\title{
Time-Kill Assay of 4-Hydroxypanduratin A Isolated from Kaempferia Pandurata Against Foodborne Pathogens
}

\author{
Soerya Dewi Marliyana ${ }^{1}$, Didin Mujahidin², Yana M Syah², Yaya Rukayadi ${ }^{2}$ \\ ${ }^{1}$ Department of Chemistry, University of Sebelas Maret, Surakarta, Indonesia \\ ${ }^{2}$ Department of Chemistry, Institut Teknologi Bandung, Bandung, Indonesia \\ ${ }^{3}$ Laboratory of Natural Products, Institute of Bioscience, Universiti Putra Malaysia, \\ Serdang, Selangor Darul Ehsan, Malaysia \\ *email: msoerya@staff.uns.ac.id
}

Received July 13, 2017; Accepted November 14, 2017; Available online November 30, 2017

\begin{abstract}
Time-kill assay was performed for 4-hydroxypanduratin A that was isolated from Kaempferia pandurata rizhome against four important foodborne pathogens, namely Bacillus cereus ATCC 21772, Bacillu subtilis ATCC 6633, Staphylococcus aureus ATCC 29737, and Proteus mirabilis ATCC 21100. The methods have been investigated in term of Minimum Inhibitory Concentration (MIC) and killing time curve using methods of Clinical and Laboratory Standards Institute (CLSI) guidelines. The results showed that 4hydroxypanduratin A rapid acting in killing bacteria as follow: B. cereus : $1 \times \mathrm{MIC}$ for $4 \mathrm{~h}, P$. mirabilis: $4 \times \mathrm{MIC}$ for $0.5 \mathrm{~h}$, meanwhile $B$. subtilis and $S$. aureus were $1 \times \mathrm{MIC}$ for $2 \mathrm{~h}$. In conclusion, 4hydroxypanduratin A showed strong antimicrobial activity against four important foodborne pathogens.
\end{abstract}

Keywords: time-kill assay, 4-hydroxypanduratin A, foodborne pathogens

\section{INTRODUCTION}

Food is the main resource of nutrition for human so that safety and hygiene are very important for human consumption. One of the diseases is the infection caused by foodborne pathogens. It is estimated that each year has 2 million people deaths which has 1.5 million is children because of foodborne and waterborne diseases in the world (WHO, 2015). Up to now, microorganisms have become resistance to many common antibiotics due to decreasing the drug efficiencies. Research in recent years has focused on finding active molecules from natural sources which become leading compounds for the manufacture of various pharmaceutical products (Chen et al., 2012).

Natural products, especially from plants, have been considered interesting alternatives for treatment because they have a numerous variety of secondary metabolites with antimicrobial properties (Lu, Zhao, Wang, Chen, \& Fu, 2007; Sgariglia, Soberon, Sampietro, Quiroga, \& Vattuone, 2011). These secondary metabolites which are pharmacologically bioactive compounds include alkaloids (Saleem et al., 2010), flavanoids (Cushine \& Lamb, 2011; Kuete, et al. 2008; Mandalari et al., 2007), tannins (Doss, Mubarack, \& Dhanabalan, 2009), terpenoids (Sarkkahya et al., 2011; Ding et al., 2009), anthraquinones, and phenolic compounds (Yagi et al., 2012; Fang, Ye, Chen, \& Zhao, 2008; Nawrot, Lesniewicz, Pienkowska, \& Gozdzicka, 2007).

One of them is 4-hydroxypanduratin A, a chalcone derivative (flavonoid), was isolated from Kaempferia pandurata rizhome. This rizhome is known as "temu kunci", in Indonesia. Some studies indicated various biological activities of 4-hydroxypanduratin $\mathrm{A}$, including antioxidative, antimutagenic, and antivirus activities (Trakoontivakorn, 2001; Shindo, Kato, Kinoshita, Kobayashi, \& Koike, 2006; Cheenpracha, Karalai, Ponglimanont, Subhadhirasakul, \& Tewtrakul, 2006). Previously, we have been reported that 4hydroxypanduratin A showed good antibacterial activity against foodborne pathogens, namely Bacillus cereus ATCC 21772, Bacillus subtilis ATCC 6633, Escherichia coli O157:H7, Listeria monocytogenes ATCC 15313, Proteous mirabilis ATCC 21100, Vibrio parahaemolyticus. ATCC 17802, Samonella typhi ATCC 14028, Klebsiella pneumoniae ATTC13733 and Staphylococcus aureus ATCC 29737 (Marliyana, Rukayadi, Ismail, Mujahidin, \& Syah, 2015).

Here in, this study is aimed to continue our investigation to find bactericidal properties with time-kill assay. This assay was done against B. cereus, B. Subtilis, S. aureus, and $P$. mirabilis. This study is part of an advanced 
research to find new bioactive natural products from traditional Indonesian medicine.

\section{EXPERIMENTAL SECTION}

\section{Materials}

Rhizomes of $K$. pandurata were purchased from the herbal shop 'Babah Kuya', Pasar Baru, Bandung, Indonesia, and were deposited at the Laboratory of Natural Product, Institut Teknologi, Bandung. Materials for isolation were silica gel 60 (Merck, 1.07733.1000), thin layer chromatography (TLC) silica gel 60 F254 (Merck (1.05554.0001), and silica gel $60 \mathrm{G}$ (Merck, 1.07731.1000). The solvents used in this study were obtained commercially and were used further purification. There were n-hexane, acetone, ethyl acetate, methanol, and chloroform $\left(\mathrm{CHCl}_{3}\right.$, E. Merck). Reagent for antibacterial activity was DMSO (dimethyl sulfoxide), $\mathrm{NaCl}$ (p.a), and chlorhexidine (E. Merck).

\section{Bacterial strain}

The antibacterial activity of isolated compound of $K$. pandurata rizhome was evaluated against four bacterial species. They were Staphylococcus aureus ATCC 29737, Proteous mirabilis ATCC 21100, Bacillus subtilis ATCC 6633, and Bacillus cereus ATCC 21772. All of them were obtained from the American Type Culture Collection (Rockville, MD, USA). All the bacteria were grown in Muller Hinton Broth (Difco Becton Dickincon, Sparks, MD, USA) at $37{ }^{\circ} \mathrm{C}$ and maintained on Muller Hinton Agar (Difco Becton Dickincon, Sparks, MD, USA). The experiments were performed with two replications and the results were expressed as average values

\section{Instrumentation}

Isolation and purification of compounds were used vacuum liquid and radial chromatography. Identification of the pure compounds were determined based on spectroscopic analysis covering NMR $\left({ }^{1} \mathrm{H}-\right.$ NMR (500 MHz), ${ }^{13} \mathrm{C}-\mathrm{NMR}(125 \mathrm{MHz})$, HMBC, HSQC) Agilent DD2. The time-kill assay used autoclave, laminar, orbital shaker at $200 \mathrm{rpm}$, and incubator Shimadzu at $37^{\circ} \mathrm{C}$.

\section{Compound isolation and identification}

The white powder of 4Hydroxypanduratin A was isolated and identified from dried rizhome of $K$. pandurata.
Briefly, K. pandurata dried rizhome $(2.0 \mathrm{Kg})$ was powdered and extracted in maceration apparatus using acetone as solvent for $3 \times 24 \mathrm{~h}$ at room temperature. The extract was then concentrated under reduced pressure, yielding $256 \mathrm{~g}$ of the crude extract. The crude extract $(20 \mathrm{~g})$ was fractionated using vacuum liquid chromatography with mix solvent $n$-hexane : ethyl acetate $(10: 0 ; 9: 1 ; 8: 2 ; 7: 3 ; 1: 1 ; 4: 6$; $0: 10)$ to give 16 fraction (F1-F16). The purity test of isolated compound was analysed by TLC using different types of eluent. To know how the compound was pured, it can be seen from the single spot with various eluent.

The purification of fraction F13 was done using the radial chromatography (first run with $n$-hexane- $\mathrm{CHCl}_{3}$ as eluent at 2:8; second run with $n$-hexane-EtOAc as eluent at 8:2) to obtain 4-hydroxypanduratin A (12.2 mg). This compound was identified by analysis NMR data and comparised with data reported previously.

\section{Characteristic data of compound}

The characteristic data of this compound was white amorphous powder, melting point (mp.) $158-160{ }^{\circ} \mathrm{C}$. The ${ }^{1} \mathbf{H}$ NMR Spectrum $\left(\mathrm{CDCl}_{3}, 500 \mathrm{MHz}, \mathrm{CD}_{3} \mathrm{OD}\right), \delta(\mathrm{ppm}): 5.78$ $\left(5.88^{*}\right)(2 \mathrm{H}, s, \mathrm{H}-3, \mathrm{H}-5) ; 4.73\left(4.82^{*}\right)(1 \mathrm{H}$, $\left.d d, J=4.7 ; 11.6 \mathrm{~Hz}, \mathrm{H}-1^{\prime}\right) ; 2.62\left(2.69^{*}\right)(1 \mathrm{H}, m$, $\left.\mathrm{H}-2^{\prime}\right) ; 1.76\left(1.76^{*}\right)\left(3 \mathrm{H}, s, \mathrm{H}-3^{\prime}-\mathrm{Me}\right) ; 5.41$ $\left(5.41^{*}\right)\left(1 \mathrm{H}\right.$, br $\left.s, \mathrm{H}-4^{\prime}\right) ; 1.98 ; 2.37$ (1.95; $\left.2.35^{*}\right)\left(1 \mathrm{H}, m, \mathrm{H}-5^{\prime}\right) ; 3.41\left(3.45^{*}\right)(1 \mathrm{H}, d d d$, $\mathrm{J}=11.9 ; 10.6 ; 6.1 \mathrm{~Hz}, \mathrm{H}-6$ '); $2.09 ; 2.24$ (2.10; $\left.2.26^{*}\right)(1 \mathrm{H}, m, \mathrm{H}-1 ") ; 4.89\left(4.92^{*}\right)(1 \mathrm{H}, t, \mathrm{H}-$ $2 ") ; 1.51$ (1.51*) (3H, s, H-4"); 1.51 (1.51*) $(3 \mathrm{H}, s, \mathrm{H}-5 ") ; 7.06-7.21$ (7.04-7.19*) $(5 \mathrm{H}, m$, H-1"'- H6"'), and the ${ }^{13}$ C NMR Spectrum $\left(125 \mathrm{MHz}, \mathrm{CD}_{3} \mathrm{OD}\right), \delta$ (ppm): $105.5\left(106.2^{*}\right)$ (C-1); 163.2 (164.8*) (C-2); 95.0 (95.9*) (C3); 163.2 (164.8*) (C-4); 95.0 (95.9*) (C-5); $163.2\left(164.8^{*}\right)(\mathrm{C}-6) ; 53.5\left(54.5^{*}\right)\left(\mathrm{C}-1^{\prime}\right) ; 42.3$ $\left(43.4^{*}\right)\left(\mathrm{C}-2^{\prime}\right) ; 137.4\left(137.9^{*}\right)\left(\mathrm{C}-3^{\prime}\right) ; 22.7$ $\left(23.0^{*}\right)\left(\mathrm{C}-3^{\prime}-\mathrm{Me}\right) ; 120.8\left(121.7^{*}\right)\left(\mathrm{C}^{\prime} 4^{\prime}\right) ; 35.8$ $\left(36.8^{*}\right) \quad\left(\mathrm{C}-5^{\prime}\right) ; \quad 37.0 \quad\left(37.8^{*}\right) \quad\left(\mathrm{C}-6^{\prime}\right) ; 28.9$ (29.5*) (C-1"); 124.3 (125.4*) (C-2”); 131.5 $\left(131.7^{*}\right)(\mathrm{C}-3 ”) ; 17.8$ (17.9*) (C-4”); 25.6 $\left(25.9^{*}\right)\left(\mathrm{C}-5^{\prime \prime}\right) ; 147.3$ (148.3*) (C-1"'); 127.0 (128.0*) (C-2"”, C-6"'); 128.2 (128.9*) (C-3"', C-5"'); 125.4 (126.2*) (C-4"'); 206.6 (207.0*) $(\mathrm{C}=\mathrm{O})$. (Note: * the literature data: Tuchinda et al., 2002, $\mathrm{CD}_{3} \mathrm{COCD}_{3}, 300 \mathrm{MHz}\left({ }^{1} \mathrm{H}\right) ; 75 \mathrm{MHz}$ $\left.\left({ }^{13} \mathrm{C}\right)\right)$.

\section{Determination of minimal inhibitory concentration (MIC)}


The MIC was determined according to previous standardization as recommended by the Clinical Laboratory Standards Institute (CLSI) guidelines. The 4-Hydroxypanduratin A was tested for antibacterial activity against four species of bacteria mentioned above in a 96-well microtiter plate using two fold standard broth microdilution method with an inoculum of approximately $10^{6} \mathrm{CFU} / \mathrm{mL}$. Shortly, a $100 \mu \mathrm{L}$ of each compounds stock solution $(1 \%$ or $10000 \mu \mathrm{g} / \mathrm{mL})$ was stirred and diluted two-folds with the test organism in 100 $\mu \mathrm{L}$ of Mueller Hinton broth (MHB, Difco, Sparks, MD, USA). The highest concentration of the compound was in column 12 of the microtiter plate, while column 3 contained the lowest concentration. The first column served as negative growth control (only MHB, no inoculum and antibacterial agent) while the second column is the positive growth control for all samples (only MHB and inoculum). The microtiter plate was then incubated aerobically at $37^{\circ} \mathrm{C}$ for $24 \mathrm{~h}$. The MIC was defined as the lowest concentration of antibacterial agent that resulted in the complete inhibition of visible growth (Rukayadi, Lee, Han, Yong, \& Hwang, 2009). In this assay, $500 \mu \mathrm{g} / \mathrm{mL}$ of chlorhexidine (CHX) was used as positive control.

\section{Time-kill assay}

The time-kill kinetics antibacterial study of the 4-hydroxypanduratin A of $K$. pandurata rizhome was carried out to assess the killing rate of the compound within a given contact time. In this study, the assay was done according to CLSI reference method, with slightly modification. The inoculum suspension of these bacteria was approximately $10^{6} \mathrm{CFU} / \mathrm{mL}$. The compound was diluted with the MHB medium containing inoculum to get final concentrations of $0 \times$ MIC, $0.5 \times$ MIC, $1 \times$ MIC, $2 \times$ MIC, and $4 \times$ MIC for each bacterial species. Cultures $(1 \mathrm{~mL}$ final volume) were incubated at $37^{\circ} \mathrm{C}$ with 200 $\mathrm{rpm}$ agitation. At pre-determined time points $(0,0.5,1,2$, and $4 \mathrm{~h}), 100 \mu \mathrm{L}$ aliquots were displaced and transferred to microcentrifuge tubes. The aliquot was serially diluted 1:100 in $0.9 \% \mathrm{NaCl}$ and plated onto NA. The bacterial subculture plates were incubated for 18 to 24 hours at $35-37{ }^{\circ} \mathrm{C}$. After incubation, the agar plates were observed visually for the presence of growth. The colony forming units (CFUs) were enumerated, and the number of survivors at each exposure time was determined. The number of colonies formed on the plates after incubation at $37^{\circ} \mathrm{C}$ for $24 \mathrm{~h}$ was counted and the number of $\mathrm{CFU} / \mathrm{mL}$ was calculated. Assays were carried out in duplicate. Time-kill curves were constructed by plotting the $\log \mathrm{CFU} / \mathrm{mL}$ versus time (Rukayadi et al., 2010).

\section{RESULTS AND DISCUSSION}

Nowadays, antibiotic resistance is one of the greatest threats to public health, so it is absolutely necessary to search new antibacterial agents. Antibiotic resistance can be intrinsic or acquired and can be transmitted within the same or different species of bacteria. The mechanisms can be divided into different categories: (i) modification of the active site of the target resulting in a reduction in the efficiency of binding of the antibiotic; (ii) direct destruction or modification of the antibiotic by enzymes produced by the bacterium; (iii) efflux or removal of antibiotic from the cell cause a reduced amount of antibiotic; or (iv) production of an alternative target that is resistant to inhibition by the antibiotic (metabolic by-pass) (Hemaiswarya, Kruthiventi, \& Doble, 2008; Langeveld, Veldhuizen, \& Burt, 2014).

Investigating the natural products from plants could be a fascinating alternative therapy (Langeveld et al., 2014; Miklasin'ska et al., 2016; Schäfer, \& Wink, 2009). Medicinal plants have been unique sources of medicines and constituted the most common human use of biodiversity (Hiremath \& Taranath, 2010). The traditional use of medicinal plants are used worldwide for thousands of years with more than $80 \%$ of the world's population depending on traditional medicines for various diseases, included they will be useful for the treatment of bacterial infections (Patel \& Coogan, 2008). Previous studies have been implemented in different parts of the extract plant products for screening antibacterial activity (Olajuyigbe \& Afolayan, 2012). Plants produce highly bioactive compounds that permit them to interact with other organisms in their environement. Many of these substances contribute to the resistance to diseases. Many researchers have evaluated and reported the bioactivity of plant extracts and the isolated constituents against the serious infectious organisms (Saleem et al., 2010; Konaté et al., 2012). 
Table 1. Antibacterial activity of the 4-hydroxypanduratin A

\begin{tabular}{lcc}
\hline \multirow{2}{*}{\begin{tabular}{c} 
Tested bacterial isolates \\
\cline { 2 - 3 }
\end{tabular}} & 4-hydroxypanduratin A & $\begin{array}{c}\text { Chlorhexidine } \\
\text { (positive control) }\end{array}$ \\
\cline { 2 - 3 } Staphylococcus aureus ATCC 29737 & 1.2 & MIC $(\mu \mathrm{g} / \mathrm{mL})$ \\
Proteous mirabilis ATCC 21100 & 2.3 & 0.5 \\
Bacillus subtilis ATCC 6633 & 4.7 & 0.5 \\
Bacillus cereus ATCC 21772 & 37.5 & 3.9 \\
\hline
\end{tabular}

The concentrations of 4-hydroxypanduratin $\mathrm{A}$ and chlorhexidine were $600 \mu \mathrm{g} / \mathrm{mL}$ and $500 \mu \mathrm{g} / \mathrm{mL}$, respectively

Isolation work on rhizomes extracts of $K$.pandurata has led to the identification of 4hydroxypanduratin A (white powder). Chemical structure of this compound was showed in Figure 1. The MICs of 4hydroxypanduratin A against four foodborne pathogens are obtained from our previous report (Marliyana et al., 2015). The results of minimum inhibitory concentration (MIC) of the compound against the susceptible bacteria are presented in Table 1. Our results showed that 4-hydroxypanduratin A was significant inhibitory properties against these tested bacteria. This compound also exhibited high activity against $S$. aureus ATCC 29737, $P$. mirabilis ATCC 21100, and B. subtilis ATCC 6633 (MIC range at 1.2 to $4.7 \mu \mathrm{g} / \mathrm{mL}$ ), while the MIC was good activity for B. cereus ATCC 21772 (MIC at $37.5 \mu \mathrm{g} / \mathrm{mL}$ ).

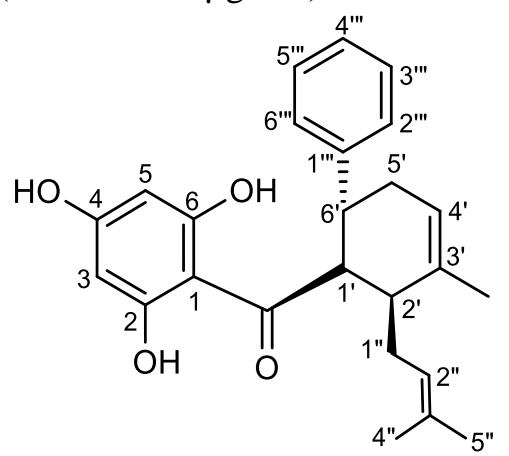

Figure 1. Chemical structure of 4hydroxypanduratin A.

Some authors have advised criteria based on MIC values for the determination of the antimicrobial potential of compounds isolated from natural sources. The MIC values below $100 \mu \mathrm{g} / \mathrm{mL}$ have good antimicrobial activity (Ayres et al., 2008; Regasini et al., 2010); an MIC from 100 to $500 \mu \mathrm{g} / \mathrm{mL}$ represents moderate antimicrobial activity; an MIC from 500 to $1000 \mu \mathrm{g} / \mathrm{mL}$ represents weak activity; an MIC above $1000 \mu \mathrm{g} / \mathrm{mL}$ suggests that the substance is inactive. (Fonseca et al., 2013; Gibbons, 2008; Kuete, 2010). Based on these criteria, this compound was included an active compound. So we continued to investigate the Minimal Inhibitory Concentration (MIC) with time kill assay.

The time-kill assays have been widely used for in vitro investigations of new antimicrobial agents as these provide descriptive (qualitative) information on the pharmacodynamics of antimicrobial agents (Olajuyigbe \& Afolayan, 2012). This assay unlike an MBC/MIC assay, allows the determination of the speed of cidal activity of the compound (Aiyegoro, Afolayan, \& Okoh, 2009). In this study, the time-kill assay was done on the vegetative cells of $S$. aureus ATCC 29737, P. mirabilis ATCC 21100, B. subtilis ATCC 6633, and B. cereus ATCC 21772. Hence, the time-kill curve conducted to determine how long all bacteria are necessary for 4-hydroxypanduratin $\mathrm{A}$ to completely eliminate these pathogens. The curves were determined to assess the correlation between MIC and bactericidal activity of 4hydroxypanduratin $\mathrm{A}$ at concentrations ranging from 0 fold MIC to 4 fold MIC.

The compound was rapidly bactericidal at $4 \times$ MIC for $P$. mirabilis after $0.5 \mathrm{~h}$ incubation. The bactericidal endpoint for $B$. cereus was reached after $4 \mathrm{~h}$ at concentration of $1 \times$ MIC of incubation. Meanwhile $B$. subtilis and $S$. aureus were completely eliminate after $2 \mathrm{~h}$ incubation at concentration of $1 \times$ MIC. 


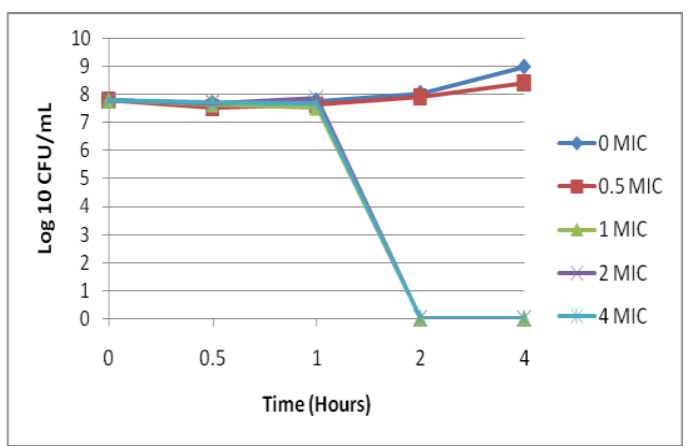

(a)

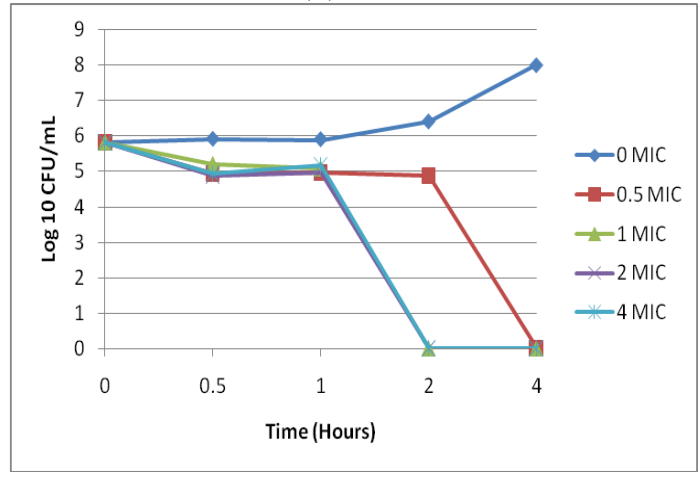

(c)

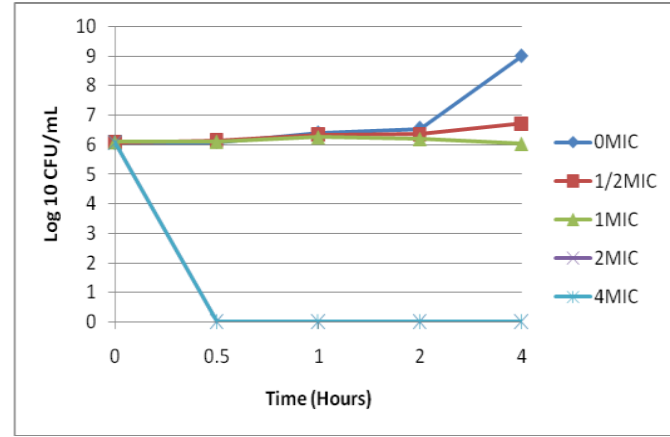

(b)

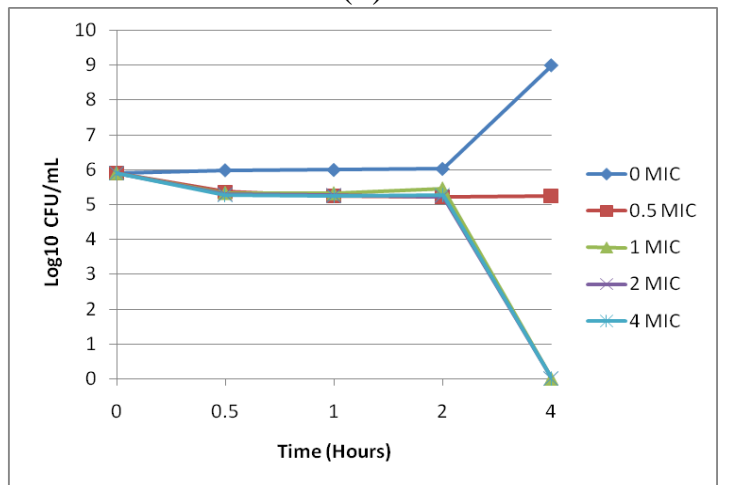

(d)

Figure 2. Time-kill curve of 4-hydroxypanduratin A against (a) S. aureus, (b) P. mirabilis, (c) B. subtilis, and (d) B. cereus.

The results of the time-kill assay are presented in Figure 2. In this study, our data showed that the response of the bacteria to the tested compound (4-hydroxypanduratin A) varied among the strains, concentration and time dependent. The differences in susceptibility may be due to the differences in cell wall composition and/or genetic content of their bacteria. The antibacterial activity is most likely due to the adsorption of compounds causing membrane disruption, subsequent leakage of cellular contents and cell death (Karaman et al., 2003; Negi, 2012).

Base on literature study, the 4hydroxipaduratin A was a chalcone derivative of flavonoid. Some investigator have reported that polyphenols, such as tannins and flavonoids, are important antibacterial activity (Cushine \& Lamb, 2011). The antimicrobial activity of flavonoids is due to their ability to complex with extracellular and soluble protein and to complex with bacterial cell wall while that of tannins may be related to their ability to inactivate microbial adhesions, enzymes and cell envelop proteins (Cowan, 1999). The timekill assay was demonstrated that 4hydroxypanduratin A showed good bactericidal activity for those bacteria and can be used to determine the dose of 4hydroxypanduratin A for further clinical tests.
Finding new antibacterial agents is a matter of urgency as antibiotic resistance in infectious diseases has become a global issue (Gould, 2008). Although traditionally these agents have been obtained from microbes, in recent years much attention has been devoted to plants as an alternative source of the agents (Cushine \& Lamb, 2011; Saleem et al., 2010). Among plant-derived compounds from traditional medicine, 4-hydroxypanduratin $\mathrm{A}$ isolated from the rhizome of $K$. pandurata has been proven as a promising new antibacterial agent. Thus, this paper reports for the first time the time-kill assay of 4-hydroxypanduratin A.

\section{CONCLUSION}

Phytochemical study integrated with biological assay has led to the isolation and identification of an active compound, namely 4hydroxypanduratin $\mathrm{A}$ as the antibacterial activities, from the rhizome $K$. pandurata. The time-kill studies have provided valuable information on the rate, concentration and potential action of antibacterial agents in vitro. Further time-kill test showed that this compound was strong bactericidal agents against four tested foodborne pathogens: $S$. aureus ATCC 29737, P. mirabilis ATCC 21100, B. subtilis ATCC 6633, and B. cereus ATCC 21772. The results suggested that 4- 
hydroxypanduratin $\mathrm{A}$ can be used as a potential candidate antibacterial agents and may serve as leads for developing new antimicrobial agents.

\section{ACKNOWLEDGEMENTS}

The financial support from a Grant for Penelitian Disertasi Doktor with contract number: 353/UN27.21/PN/2016, from the Higher Education Directorat, Ministry of Education, Republic of Indonesia, is gratefully acknowledged.

\section{REFERENCES}

Aiyegoro, O. A., Afolayan, A. J., \& Okoh, A. I. (2009). In vitro antibacterial time kill studies of leaves extracts of Helichrysumlongifolium. Journal of Medicinal Plants Research, 3 (6), 462467.

Ayres, M. C. C., Brandão, M. S., VieiraJúnior, G. M., Menor, J. C. A. S., Silva, H. B., Soares, M. J. S., \& Chaves, M. H. (2008). Atividade antibacteriana de plantas úteis e constituintes químicos da raiz de Copernicia prunifera. Brazilian Journal of Pharmacognosy, 18, 90-97.

Cheenpracha, S., Karalai, C., Ponglimanont, C., Subhadhirasakul, S., \& Tewtrakul, S. (2006). Anti-HIV-1 protease activity of compounds from Boesenbergia pandurata. Bioorganic \& Medicinal Chemistry, 14, 1710 -1714.

Chen, J., Li, Y., Yang, L. Q., Li, Y. Z., Nan, Z. B., \& Gao, K. (2012). Biological activities of flavonoids from pathogenicinfected Astragalus adsurgens. Food Chemistry, 131, 546-551.

Cowan, M. M. (1999). Plants products as antimicrobial agents. Clinical Microbiology Reviews, 12, 564-582.

Cushine, T. P. M., \& Lamb, A. J. (2011). Recent advances in understanding the antibacterial properties of flavonoids. International Journal of Antimicrobial Agents, 38, 99 -107.

Ding, Q., Yang, L. X., Yang, H. W., Jiang, C., Wang, Y. F., \& Wang, S. (2009). Cytotoxic and antibacterial triterpenoids derivatives from Clematis ganpiniana. Journal of Ethnopharmacology, 126, 382-385.

Doss, A., Mubarack, H. M., \& Dhanabalan, R. (2009). Pharmacological importance of
Solanum trilobatum. Indian Journal of Science and Technology., 2, 41- 43.

Fang, J. J., Ye, G., Chen, W. L., \& Zhao, W. M. (2008). Antibacterial phenolic components from Eriocaulon buergerianum. Phytochemistry, 69,1279-1286.

Fonseca, A. P., Estrela, F. T., Moraes, Th. S., Carneiro, L. J., Bastos, J. K., Dos Santos, R. A., Ambrósio, S. R., Martins, C. H. G., \& Veneziani, R. C. S. (2013). In Vitro Antimicrobial Activity of PlantDerived Diterpenes against Bovine Mastitis Bacteria. Molecules, 18, 7865 7872.

Gibbons, S. (2008). Phytochemicals for bacterial resistance: Strengths, weaknesses and opportunities. Planta Medica, 74, $594-602$.

Gould, I. M. (2008). The epidemiology of antibiotic resistance. International Journal of Antimicrobial Agents, 32(Suppl. 1), S2.

Hemaiswarya, S., Kruthiventi, A. K., \& Doble, M. (2008). Synergism between natural products and antibiotics against infectious diseases. Phytomedicine, 15, 639-652.

Hiremath, V. T., \& Taranath, T. C. (2010). Traditional phytotherapy for snake bites by tribes of Chitradurga District, Karnataka, India. Ethnobotanical Leaflets, 14, 120-125.

Karaman, I., Sahin, F., Gulluce, M., Ogutcu, H., Sngul, M., \& Adiguzel, A. (2003). Antimicrobial activity of aqueous and methanol extracts of Juniperus oxycedrus L. Journal of Ethnopharmacology, 85, 231-235.

Konaté, K., Adama Hilou, A., Mavoungou, J. F., Lepengué, A. N., Souza, A., Barro, N., Datté, J. Y., M'Batchi, B., \& Nacoulma, O. G. (2012). Antimicrobial activity of polyphenol-rich fractions from Sida alba L. (Malvaceae) against cotrimoxazol-resistant bacteria strains. Annals of Clinical Microbiology and Antimicrobials, 11 (5), 1-6.

Kuete, V. (2010). Potential of Cameroonian plants and derived products against microbial infections: A Review. Planta Medica, 76 (14), 79-91.

Kuete, V., Ngameni, B., Simo, C. C, Tankeu, P. K, Ngadjui, B. T., Meyer, J. I., Lall, N., \& Kuiate, J. R. (2008). 
Antimicrobial activity of the crude extracts and compounds from Ficus chlamydocarpa and Ficus cordata (Moraceae). Journal of Ethnopharmacology, 120, 17-24.

Langeveld, W. T., Veldhuizen, E. J., \& Burt, S. A. (2014). Synergy between essential oil components and antibiotics: A review. Critical Reviews in Microbiology, 40, 76-94.

Lu, Y., Zhao, Y. P., Wang, Z. C., Chen, S. Y., \& Fu, C. X. (2007). Composition and antimicrobial activity of the essential oil of Actinidiamacrosperma from China. Natural Product Research, 21 (3), 227 233.

Mandalari, G., Bennett, R. N., Bisignano, G., Tombetta, D., Saija, A., Faulds, C. B.,Gasson, M. J., \& Narbad, A. (2007). Antimicrobial activity of flavonoids extracted from bergamot (Citrus bergamia Risso) peel, a byproduct of the essential oil industry. Journal of Applied Microbiology., 103, 2056 - 2064.

Marliyana, S. D., Rukayadi, Y., Ismail, I. S., Mujahidin, D., \& Syah, Y. M. (2015). Inhibitory properties of panduratin A and 4-hydroxypanduratin A isolated Kaempferia pandurata against some pathogenic bacteria. Current Topics in Toxicology, 11, $23-28$.

Miklasin'ska, M., Kepa, M., Wojtyczka, R. D., Idzik, D., Dziedzic, A., \& Wasik, T. J., (2016). Catechin hydrate augments the antibacterial action of selected antibiotics against Staphylococcus aureus clinical strains. Molecules, 21, 244.

Nawrot, R., Lesniewicz, K., Pienkowska, J., \& Gozdzicka, J. A. (2007). A novel extracellular peroxidase and nucleases from amilky sap of Chelidonium majus. Fitoterapia, 78 (7-8), 496 - 501.

Negi, P. S., (2012). Plant extracts for the control of bacterial growth: Efficacy, stability and safety issues for food application. International Journal of Food Microbiology, 156 (1), 7-17.

Olajuyigbe, O. O., \& Afolayan, A. J. (2012). In Vitro Antibacterial and Time-Kill Assessment of Crude Methanolic Stem Bark Extract of Acacia mearnsii De Wild against Bacteria in Shigellosis. Molecules, 17, 2103-2118.
Patel, M., \& Coogan, M. M. (2008). Antifungal activity of the plant Dodonaea viscosa var. angustifolia on Candida albicans from HIV-infected patients. Journal of Ethnopharmacology, 118 (1), 173-176.

Regasini, L. O., Pivatto, M., Scorzoni, L., Benaducci, T., Fusco-Almeida, A. M., Giannini, M. J. S. M., Barreiro, E.J., Siva, D.H.S., \& Bolzani, V.S. (2010). Antimicrobial activity of Pterogyne nitens Tul., Fabaceae, against opportunistic Fungi. Brazilian Journal of Pharmacognosy, 20, 706-711.

Rukayadi, Y., Lee, K., Han, S., Yong, D., \& Hwang, J. K. (2009). In Vitro Activities of Panduratin A against Clinical Staphylococcus Strains. Antimicrobial Agents and Chemotherapy, 53 (10), 4529-4532.

Rukayadi, Y., Han, S., Yong, D., \& Hwang, J. K. (2010). In vitro antibacterial activity of panduratin A against enterococci clinical isolates. Biological and Pharmaceutical Bulletin, 33 (9) 14891493.

Saleem, M., Nazir, M., Ali, M. S., Hussain, H., Lee, Y. S., Riaza, N. \& Jabbar, A. (2010). Antimicrobial natural products: an update on future antibiotic drug candidates. Natural Product Reports, 27, 238-254.

Sarıkahya, N. B., Pekmez, M., Arda, N., Kayce, P., Yavasoglu, K., \& Kırmızıgul, S. (2011). Isolation and characterization of biologically active glycosides from endemic Cephalaria species in Anatolia. Phytochemistry Letters, 4, 415-420.

Schäfer, H., \& Wink, M. (2009). Medicinally important secondary metabolites in recombinant microorganisms or plants: Progress in alkaloid biosynthesis. Biotechnology Journal, 4, 1684.

Sgariglia, M. A., Soberon, J. R., Sampietro, D. A., Quiroga, E. N., \& Vattuone, M. A. (2011). Isolation of antibacterial components from infusion of Caesalpinia paraguariensis bark: A bioguided phytochemical study. Food Chemistry, 126 (2), 395-404.

Shindo, K., Kato, M., Kinoshita, A., Kobayashi, A., \& Koike, Y. (2006). Analysis of antioxidantactivities contained in the Boesenbergia pandurata Schult. Rhizome. Bioscience, 
Biotechnology and Biochemistry, 70, $2281-2284$.

Trakoontivakorn, G., Nakahara, K., Shinmoto, H., Takenaka, M., Onishi-Kameyama, M., \& Ono, H. (2001). Structural analysis of a novel antimutagenic compound, 4-hydroxypanduratin A, and the antimutagenic activity of flavonoids in a Thaispice, fingerroot (Boesenbergia pandurata Schult.) against mutagenic heterocyclicamines. Journal of Agricultural and Food Chemistry, 49, 3046 - 3050 .

Tuchinda, P., Reutrakul, V., Claeson, P., Ponprayoon, U., Sematong, T., Santosuk, T., \& Taylor, W.C. (2002).
Anti-inflammatory cyclohexenyl chalcone derivatives in Boesenbergia pandurata. Phytochemistry, 59, 169173.

World Health Organization, World Health Report. http://www.who.int/campaigns/worldhealth-day/

Yagi, S., Chrétien, F., Duval, R. E., Fontanay, S., Maldini, M., Piacente, S., Henry, M., Chapleur, Y., \& Mattar, D. L. (2012). Antibacterial activity, cytotoxicity and chemical constituents of Hydnora johannis roots. South African Journal of Botany, 78, 228-234. 